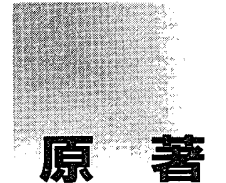

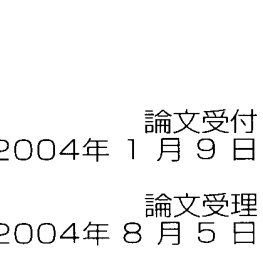

Code No. 390

\section{乳癌のセンチネルリンパシンチグラフィとMDCTによる 三次元画像合成法の検討}

\author{
太田勝郎 · 竹内美幸 - 戸崎光宏 ${ }^{1)} \cdot$ 飯田哲也 \\ 大下 崇・高村公裕・藤洞 実・赤沢宏允 \\ 東京慈恵会医科大学附属第三病院放射線部 \\ 1 ) 東京慈恵会医科大学附属第三病院放射線科
}

\section{緒 言}

近年, 外科腫瘍学の分野に掞いて所属リンパ節転移 の陽性率が低い早期癌に対して，リンパ節郭清の縮小 や省略が検討されている。所属リンパ節郭清の適否 は，原発巣からのリンパ流を直接受けるリンパ節(セ ンチネルリンパ節： sentinel lymph node以下SN)の転 移の有無により決定される (sentinel node navigation surgery：以下SNNS). 乳癌においては, SNNSによる 腋窗リンパ節郭清の縮小により，術後の上肢浮腫や挙 上困難などの合併症は有意に低下する。

$\mathrm{SN}$ の同定法としては色素を用いる方法と放射性医 薬品を用いる方法(RI法)，またはその併用法が行われ ている1 -9). RI法は色素法に比べその検出率が高く7), また子期しないリンパ流にも対応できることが利点で ある ${ }^{8)}$ 。しかし，SNの解剖学的位置の同定が困難であ り，術中に指向性の強い小型ガンマ線検出器でのサー
ベイには熟練を要するという欠点がある8).

われわれは, 乳癌の広がり診断において多列検出器 型CT(以下MDCT) を用いており ${ }^{10)}$, MDCT画像とシ ンチグラフィの三次元画像合成によるSNの解剖学的 位置関係の把握を試みだ1)。今回はさらに症例を重 ね, 三次元画像合成の有用性や問題点を検討したので 報告する。

\section{1. 対象および方法}

\section{1-1 対象}

腫瘤径が $3 \mathrm{~cm}$ 以下の原発性乳癌で，触診によるリン パ節転移を認めない連続25症例である。全例女性で, 平均年齢は57.5歳である。また 1 例はアレルギーの既 往により造影CTが施行できず，撮影補助台を用いて 胸部単純CTを行った。

\title{
Efficacy of Three-dimensional Image Fusion of Lymphoscintigraphy and MDCT Data Sets in Breast Cancer
}

\author{
KATSUROU OHTA, YOSHIYUKI TAKEUCHI, MITSUHIRO TOZAKI, ${ }^{1)}$ TETSUYA IIDA, \\ TAKASHI OHSHITA, KIMIHIRO TAKAMURA, MINORU FUJIOKA, \\ and HIROMITSU AKAZAWA
}

Radiological Division, Daisan Hospital, Jikei University School of Medicine 1 ) Department of Radiology. Daisan Hospital, Jikei University School of Medicine Received Jan. 9, 2004; Revision accepted August 5, 2004; Code No. 390

\section{Summary}

The aim of this study was to evaluate the clinical usefulness of image fusion of lymphoscintigraphy with ${ }^{99 \mathrm{~m}} \mathrm{Tc}$ phytate and volume-rendering images generated by multidetector-row CT(MDCT) in patients with breast cancer. The subjects were 25 patients with clinically negative nodes. Data from the two imaging modalities were fused on a personal computer. Thirty-five axillary sentinel nodes were identified by lymphoscintigraphy. The anatomical locations of sentinel nodes in 27 patients were clearly demonstrated by 3D-fusion imaging ( 84 $\%)$. Image fusion of lymphoscintigraphy with ${ }^{99 \mathrm{~m}} \mathrm{Tc}$ phytate and volume-rendering images is helpful for sentinel node biopsy in breast cancer.

Key words: Sentinel lymph node, Lymphoscintigraphy, Multidetector-row CT (MDCT), Fusion imaging, Breast cancer 


\section{1-2 撮影補助台}

MDCTおよびシンチグラフィを同一体位にて撮影可 能な撮影補助台を発砲スチロールにて試作した(Fig. 1).CTでは患側乳頭を真上に向けた，手術と同様の 斜仰臥位を目標とし，過去のCT検査15例の傾き(平均 22度)を参考にして補助台の傾きを20度に設定した。 頭部㧍よび健側の体側面を固定し，患側上肢の挙上角 度を一定にすることで撮影体位の再現性を向上させ た。また，撮影補助台の側面の 2 点およびスライド式 の患側体側に密着させるブロックに2 点のマーキング を設置し，希釈したテクネシウムやガストログラフィ ンを配置した。

\section{1-3 シンチグラフィ}

${ }^{99 \mathrm{~m} T c-p h y t a t e ~} 10 \mathrm{MBq} / 0.1 \mathrm{ml}$ 腫瘍直上, 腫瘍近傍の 皮下 3 点の計 4 点(合計 $0.4 \mathrm{ml}$ ) に投与し, ガンマカメ ラPRISM IRIX（島津製作所）で撮像した。温めたタオ ルおよびマッサージにて血行を促進させ，撮影補助台 を用いて投与 5 分後より 5 分間隔で計 30 分間，正面 からのdynamic撮像を施行した。その1時間後，3〜 4 時間後，24時間後にそれぞれ低エネルギー高分解能 コリメーターを用い正面, 斜位, 側面をマトリックス $512 \times 512$, エネルギーピーク $140 \mathrm{KeV} \pm 10 \%$ および， 体輪郭描出目的の散乱線領域を $90 \mathrm{KeV} \pm 25 \%$ エネル ギーウィンドウにて10分間(24時間後は15分間)のシン チグラフィを撮像した. 注射部位は専用のアーチファ クト低減フィルターにて遮蔽した。撮影補助台の4 点 と胸骨柄上端および剣状突起下端の計 6 点に，それぞ れ希釈した99m Tc-phytateを入れたマーキングを設置し た. 撮像終了後, センチネルリンパ節生検 (sentinel node biopsy：以下SNB)の指標として, SN描出部位の 体側面の皮膚に放射線治療用インクにて印をつけた。 また，当施設は小型ガンマ線検出器を所有していない ため手術時のサーベイは施行していない.

なお，センチネルリンパシンチグラフィの検査実施 に際し，慈恵大学倫理委員会の承認を得るとともに， 患者からは文書にて同意を得た。

\section{1-4 MDCT}

本法のための新たなCT検査の施行はせず，乳癌の 広がり診断の検査時に撮影補助台を用い, 乳頭が真上. を向く斜仰臥位にて撮影した。4 検出器CT装置 SOMATOM Volume Zoom (Siemens Medical Solution) を使用し，造影剤は非イオン性ヨード造影剂 Iopamiron $^{\circledR 3} 370$ を $100 \mathrm{ml}$ 使用した。造影剤注入速度は $3 \mathrm{ml} / \mathrm{sec}$ とし, 造影前, 造影剤注入開始 60 秒後 (早期 相) 㧍よび 4 分後 (遅延相)に吸気時の呼吸停止下で撮 影を行った。早期相掞よび遅延相のコリメーションは

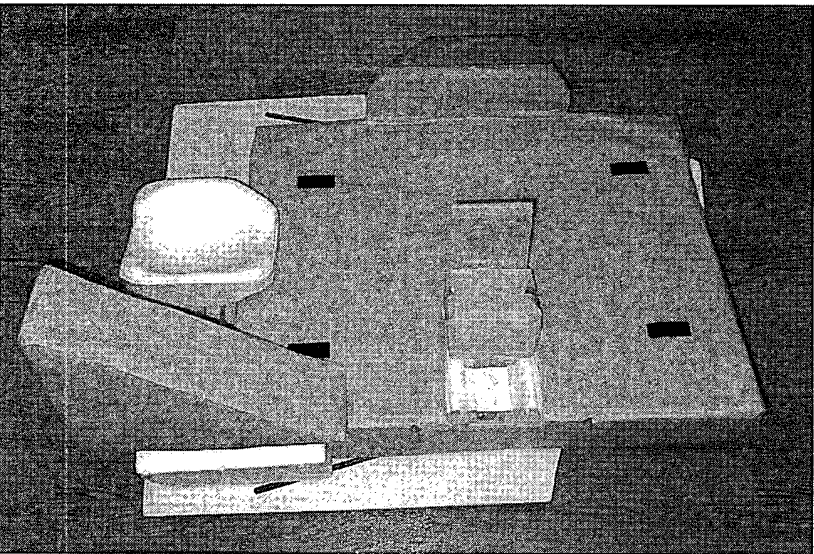

Fig. 1 Bed used to perform lymphoscintigraphy and MD$\mathrm{CT}$ in the same posture.

$1 \mathrm{~mm}$ を使用し，管電圧 $140 \mathrm{kV}$, effective mAs $100 \mathrm{mAs}$ ，ピッチ 5 にて行った。

\section{1-5 画像合成}

遅延相のvolume dataをwork stationに転送し，三次 元画像を作成した. volume rendering(VR)法を用い, 腋窩りンパ節が描出されている条件 (Fig. 2a)，マーキ ングが描出されている条件 (Fig. 2b)をそれぞれパーソ ナルコンピュータにてJPEG画像に変換した。シンチ グラフィも同様に体輪郭の強調されている画像 (Fig. 2c）, SNの描出されている画像(Fig. 2d)を作成しJPEG 画像に変換した。帛れぞれをパーソナルコンピュー夕 にてアプリケーションソフトウエアPhotoShop 6.0 (Adobe system製) を用いて画像合成を行った。

まず腋筒リンパ節の描出条件VR画像を背景とし， マーキングが描出されているVR画像をレイヤー1, 体 輪郭の強調されたシンチグラフィをレイヤー2, SNの 描出されたシンチグラフィをレイヤー 3 とし，マーキ ングを参考にVR画像とシンチグラフィの拡大率を揃 える。次に背景の上にレイヤー1を重ね, レイヤー 2 をマーキングおよび体輪郭が揃うように重ねる。さら にレイヤー3をマーキングが揃うように重ねたらレイ ヤー1，レイヤー 2 を消去し，背景とレイヤー 3 のみ が重なった状態にする。最後に不透明度を調整し乗算 にて画像合成を得る(Fig. 2e，f).

\section{1-6 評価方法}

シンチグラフィ(静態画像)で描出されるhot spotを $\mathrm{SN}$ と定義し，SNとVR画像のリンパ節との一致率を検 討した.SNの部位にとらわれず画像合成を行い，SN の部位にVR画像のリンパ節が認められるものを一致 と判断した。

また，センチネルシンチグラフィおよびVR画像の 

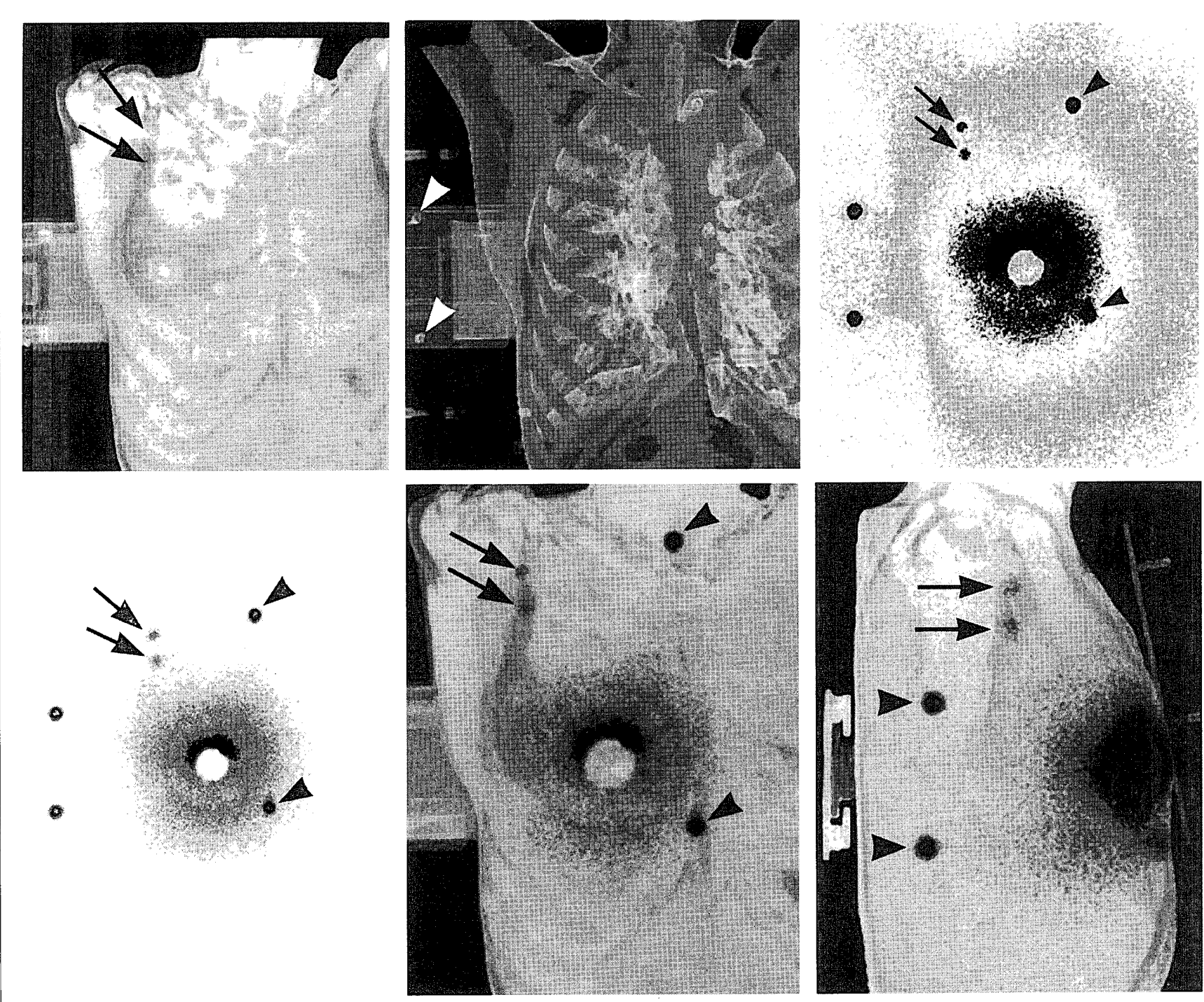

Fig. 2 (a) Volume-rendering image obtained $4 \mathrm{~min}$ after intravenous injection of contrast material shows axillary lymph node (arrow).

(b) Volume-rendering image assigned strong opaqueness shows bone and dense marking (arrowhead).

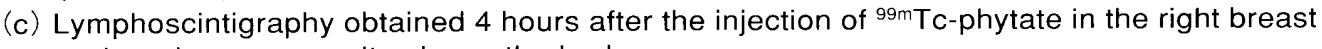
assigned strong opacity shows the body.

(d) Lymphoscintigraphy obtained 4 hours after the injection of ${ }^{99 \mathrm{~m}} \mathrm{Tc}$-phytate in the right breast shows axilla hot node (arrow) and marking (arrowhead).

(e), (f) Three-dimensional fusion images of lymphoscintigraphy obtained 4 hours after the in-

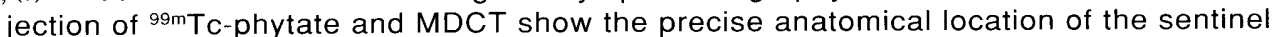
node (arrow) and marking (arrowhead).

合成の指標として，マーキングと散乱線により描出さ れた体輪郭のどちらも有效であったものを $\mathrm{A}$ 群，マー キングのみが有効であったものを $\mathrm{B}$ 群，体輪郭のみが 有効であったものをC群，マーキングで合わせ，体輪 郭をもとに微調整することで一致をみたものをD群， 一致をみなかったものを群と分類し，それぞれの一 致率を求め, 画像合成の指標について検討を行った。

判定は斜位像抢よび側面像の 2 方向でそれぞれ行 い，放射線科医師 1 名，診療放射線技師 2 名にて視 覚的に評価し，評価の分かれた症例は合議により最終
判定とした.

また，手術時の色素法において三次元合成覀像から 予測された部位に染色されたリンパ節が存在するかを 外科医が確認した。

\section{2. 結 棵}

25例中20例にシンチグラフィにてSNの検出があ り，検出されたSNの数は 1 症例当たり 1 個から 2 個 で，合計32個 (平均 1.2 個)であり三次元画像合成は全 例可能であったＳSNとVR画像のリンパ節が一致と判 
断したのは27個，不一致と判断したものが4 個であ り，一致率は84\%であり1個はアレルギーの既往によ り造影CTが施行できなかった症例で一致の判定はで きなかった。

また，画像合成指標の一致率はA群 9 個 $28.1 \% ， B$ 群 1 個 $3.1 \%$ ，C群 3 個9.3\%，D群 14 個43.8\%，E群 4 個 $12.5 \%$ であり1個は上記の理由で判定はできなかっ た (Table).

手術時に色素法を併用した16例中10例が同部位に染 色されたりンパ節の存在が確認でき，1例が位置の不 一致であった。残りの5例は色秦法にて染色されたり ンパ節を検出しなかった。シンチグラフィにてSNの 描出されなかった 5 例と，手術時の色素法に拈いて染 色されたリンパ節を認めなかった 5 例は同一症例であ った。

\section{3. 龵 察}

手術時に色素法により染色されたりンパ節を脂肪組 織のなかから探し出すSNBは術者に与えるストレスが 大きいため，SNの解剖学的位置情報を術前に把握す ることは臨床上有用である。今回の検討に扔いて，三 次元合成画像上のSNとVR画像のリンパ節の一致率は 高く $(84 \%)$, SNの解剖学的位置情報の把握に有效で ある。またCTを用いて患側乳輪下に非イオン性造影 剂を皮下注入し，3D-CTによりリンパ路の描出を行い $\mathrm{SN}$ と血管や大胸筋などの関係を術前に把握する手法 も報告されている12). 空間分解能に優れるCTを用い てリンパ路全体を描出することは有用であるが，SN 自体の同定やその定義に関してさらに検討が必要と考 えられる。一方，本法はシンチグラフィを重ね合わせ ることで外科医に有用な情報となる大胸筋とSNとの 位置関係の把握も可能であり, 術中ナビゲーション画 像としてさらに有用な情報を得ることができると考え た.

画像合成指標の検討においては，マーキングのみが 有効であったB群の一致率が3.1\%と最も低く、マーキ ングで合わせ体輪郭にて微調整することで一致したD 群が最も高い43.8\%であったが，これは体表から胸骨 柄上端および剣状突起下端マーキングをつけているた め，体形により実際の脸骨と若干のずれを生じたため だと思う。また，マーキングと散乱線による体輪郭の 両方が一致したA群と, マーキングで合わせ体輪郭に て微調整することで一致したD群を合わせると71.9\% と高い一致率となり，予想以上に体輪郭が良い指槽と なった。これは撮影補助台を用いることでほぼ同じ体 位をとることが可能であったためと考えられる。した がって今可の検討では，撮影補助台のマーキングによ りそれぞれの桩大率を揃え胸骨柄上端および㗆状突起
Table Coincidence ratio of all fusion methods using markers and scatter images.

\begin{tabular}{ccc}
\hline \hline group & No. of Lymph & coincidence ratio $(\%)$ \\
\hline A & 9 & 28.1 \\
B & 1 & 3.1 \\
C & 3 & 9.3 \\
D & 14 & 43.8 \\
E & 4 & 12.5 \\
\hline
\end{tabular}

下端マーキングにより体の左右の傾きを合わせ，さら に政乱線による体輪郭と体表面が合うように微調整す ることで精度の高い合成画像が得られると考えられ， マーキングは撮影補助台に2 点，胸骨柄上端掞よび剣 状突起下端に 2 点の合計 4 点が必要と考える。今回 は胸骨柄上端捛よび剣状突起下端のマーキングが診断 の妨げとなった症例はみられなかったが，体表でのマ 一キングは診断の妨げとなる可能性があり，今㖟は数 を減らす工夫を検討している。それに伴い撮影補助台 の改食も検討中である。さらに，画像合成がより容易 に行えるソフトウエア，シンチグラフィでの体輪郭㧍 よびSNの描出に最適なガンマ線エネルギーのウィン ドウについての検討も今後の課題である.

不一致と判断した 4 個のリンパ節のうち 1 例は上 肢の挙上が困難な患者であり撮影中の体動が大きかっ たためと考えた。また，CT撮影中に機械トラブルに より遅延相の撮影が遅れ，リンパ節の造影効果が弱く なった 1 例では, VR画像上に一致したリンパ節は認 められなかったが，早期相のデー夕より作成したMPR 画像においてほぼ一致するリンパ節を確認できた。ま たアレルギーの既往により造影CTが施行できなかっ た 1 例は，三次元合成画像上に示された部位に手術時 の色素法において染色されたリンパ節を想めた。この ことから不一致例のなかにもVR画像上に描出されて いないリンパ節が存在する可能性も考えられる。

当院では小型ガンマ線検出器を用いていないが，も し小型ガンマ線検出器を持ち合わせない施設でもSNB が施行可能であれば，手術日と無関係にアイソトープ 検查を行うことも可能となる。しかし，染色されたり ンパ節がSNと同一であるかどうかは確認が困難であ り, 小型ガンマ線検出器の省略に関しては慎重になる 必要がある。また，小型ガンマ線検出器やモバイル型 半導体検出器等を本法に併用することで，さらに正確 なSNBが可能になると考えられる。

\section{4. 結 語}

1) 撮影補助台を用いることで，MDCTとリンパシンチ グラフィの三次元画像合成は全例可能であった。

2004 年 10 月 
2) SNとVR画像のリンパ節の一致率は84\%であった。

3 ）三次元合成画像はSNの解剖学的位置情報の把握に 有効であると考えられた。

4)マーキングは撮影補助台に2 点, 胸骨柄上端および 剣状突起下端に 2 点の合計 4 点が必要と考え，マー キングで合わせ，散乱線による体輪郭で補正するこ とで高いリンパ節の一致率が得られた。

5) 小型ガンマ線検出器の省略に関しては慎重に検討す る必要があり，マーキングの数や撮影補助台の改 良，さらに画像合成法の簡略化などが今後の検討課 題と考えられた。
謝 辞

本稿を終えるにあたり，ご享受をいただいた当外 科，山下晃徳先生ならびに内田賢助教授，また，ア一 チファクト低減フィルターについて助言をいただい た，東京慈恵会医科大学附属柏病院核医学検査室の諸 氏に深く御礼申し上げます。

本論文の要旨は第31回日本放射線技術学会秋季学術 大会 $(2003$ 年10月，秋田)にて発表した。

\section{参考文献}

1) 日本核医学会：七ンチネルリンパ節の核医学的検出法ガイ ドライン。核医学，36，1033-1688，(1999).

2) 藤井博史, 中原理紀, 中村佳代子, 他：センチネルリンパ 節検索抢よびイメージング RI注入のテクニック． INNERVISION，16(1)，119-121，(2001).

3) 福喜多博義, 佐藤敬, 福島 均, 他: センチネルリンパ 検索およびイメージング撮像のテクニック。 INNERVISION, 16(1)，122-126，(2001).

4) Alazraki NP, Eshima D, Eshima LA, et al.: Lymphoscintigraphy, the sentinel node concept, and the intraoperative gamma probe in melanoma, breast cancer, and other potencial cancers. Semin. Nucl Med, 27, 55-67, (1997).

5) 藤井博史 : Sentinel node concept と核医学. 新医療, 3, 122-124, (2003).

6) Mateos JJ, Vidal-Sicarts, Zanon G, et al.: Sentinel lymph biopsy in breast cancer patients: subdermal versus peritumoural radiocolloid injection. Nucl Med Commun, 22 (1), 17-24, (2001).

7) 藤井博史：これからセンチネル・リンパ節検索を始める人
に。臨床核医学, 33(6), 89-93, (2000).

8) Wong JH, Steinemann S, Jehoon Ko P, et al.: Lymphoscintigraphy in Breast Cancer: The Value of Breast. Lymphoscintigraphy in Breast Sentinel Node Staging. Clin Nucl Med, 26 (6), 502-505, (2001).

9) 横山邦彦, 道岸隆敏, 絹谷清剛, 他：センチネルリンパ節 検出法の現状と展望．映像情報 $(\mathbf{M}) ， 32(20) ， 46-49$, (2000).

10) Tozaki M, Kawakami M, Suzuki M, et al.: Diagnosis of Tis/ $\mathrm{T} 1$ breast cancer extent by multislice helical CT: a novel classification of tumor distribution. Radiation Medicine, 21, 187192, (2003).

11) 戸崎光宏, 内田 賢, 山下晃徳, 他: 乳癌のSentinel Node Biopsyに㧍けるリンパシンチグラフィとMDCTの 3 次元合 成画像. 日本医放会誌，63(8)，412-414，(2003).

12) Suga K, Yuan Y, Okada M, et al.: Brest Sentinel Lymph Node Mapping at CT Lymphography with Iopamidol: Preliminary Experience. Radiology, 230, 543-552,(2004).

Fig. 1 MDCTおよびシンチグラフィを同一体位にて撮影可能な撮影補助台

Fig. 2 (a)腋窩リンパ節 (矢印)を描出したVR画像

(b)骨掞よびマーキングを描出したVR画像

(c) 体輪郭を強調したシンチグラフィ

(d) SN (矢印)とマーキング (矢頭)を描出したシンチグラフィ

(e)，(f) 本法にて得られた三次元合成画像 